\title{
Odun dışı orman ürünlerine ilişkin paydaş farkındalığı: Orman köylüsü örneği
}

\author{
The shareholder awareness concerning the non-wood forest products: The forest villager sample
}

\section{Osman KOMUT}

Gümüşhane Üniversitesi Gümüşhane Meslek Yüksekokulu Gümüşhane, Türkiye

Eser Bilgisi/Article Info
Araştırma makalesi/Research article
DOI: 10.17474/artvinofd.489381
Sorumlu yazar/Corresponding author
Osman KOMUT
e-mail: osmankomut@gumushane.edu.tr
Geliş tarihi / Received
28.11.2018
Düzeltme tarihi / Received in revised form
02.05.2019
Elektronik erişim / Online available
06.05.2019
Anahtar kelimeler:
Odun dışı orman ürünleri
Orman köylüsü
Farkındalık
Faydalanma
Keywords:
Non wood forest products
Forest villager
Awareness
Utilization

\begin{abstract}
Özet
Son yıllarda Dünya genelinde odun dışı orman ürünlerine yönelik artan ilgi ve talep, bu kaynakların etkin ve verimli kullanımıyla birlikte sürdürülebilirliğinin sağlanmasını zorunlu kılmıştır. Bu çalışma, odun dışı orman ürünleri kaynaklarının ve faydalanmanın sürdürülebilirliğinin sağlanmasında en önemli paydaşlar arasında yer alan orman köylülerinin konuya ilişkin farkındalık düzeyinin değerlendirmesini amaç edinmiştir. Bu bağlamda, Elazığ Orman Bölge Müdürlüğü sorumluluk alanında yer alan toplam 144 orman köylüsüne yüz yüze görüşme tekniğine dayalı anket uygulaması yapılmıştır. Çalışma sonucunda, orman köylülerinin odun dışı orman ürünlerine ilişkin görüşleri arasında mesleği, orman kaynaklarından faydalanma durumu ve bu ürünleri kullanmaya başlama nedenleri değişkenlerine göre istatistiksel düzeyde anlamlı farklııklar bulunduğu $(p<0.05)$ tespit edilmiştir. Diğer yandan, odun dışı orman ürünleri kullanım nedeninin genel itibariyle eskiden gelen deneyimler olduğu ve katılımcıların büyük çoğunluğunun bu ürünlerden herhangi bir şekilde gelir elde etmediği anlaşıımıştır. Aynı zamanda çalışma sonuçları, söz konusu ürünlerin üretim ve kontrolünün devlet denetiminde olması gerektiği kanısının katılımcılar arasında yaygın bir görüş olduğunu ortaya koymuştur.
\end{abstract}

\begin{abstract}
In recent years, the raising interest and demand for non wood forest products around the world has entailed its durability as well as the effective and productive utilization of these resources. This study aims the evaluation of the awareness levels of forest villagers, who are among the most important shareholders in obtaining the sustainability and utilization of non wood forest product resources, concerning this issue. In this context, a survey application based on the face to face interview was conducted to a total of 144 forest villagers in the responsibility area of Elazığ Forest District Directorate. As a result of the study, statistically significant differences $(p<0.05)$ have been detected in the views of forest villagers concerning the non wood forest products according to variables of occupation, reasons for starting to use these products, utilization of forest resources. On the other hand, it has been understood that the reason for the usage of non wood forest products generally originates from the past experiences and most of the participants doesn't earn any income from these products. At the same time, study findings have revealed that having production and control of products in question state mandated is a common view between participants.
\end{abstract}

\section{GiRiş}

Odun dışı orman ürünleri (ODOÜ), orman ve ağaç kaynaklı odun haricindeki biyolojik ve mineral esaslı ürünlerin yanı sıra mantarlar, orman humusu ve orman örtüsü de dâhil ürünler olarak tanımlanmaktadır (OGM 2016). Diğer yandan, orman alanlarından elde edilen odun esaslı ürünler dışındaki her türlü faydalanmanın ODOÜ kapsamına girdiğini bildiren tanımlamaların yapıldığı da bilinmektedir (Türker ve ark. 2002).

Dünya genelinde yaşanan ekonomik ve sosyal gelişmeler ormanların çevresel, biyolojik ve rekreasyonel niteliklerinin önemini ve odun dışı faydalanma gereksinimini artırmıştır (Janse and Ottitsch 2005). ODOÜ'ler dünya nüfusunun yaklaşık \%80 kadarı için vazgeçilmez gıda, tıbbi ve aromatik bitki kaynağını oluşturmasının yanı sıra sağladığı gelir dolayısıyla ekonomik kalkınmada giderek daha önemli hale gelmektedir (Komut ve Öztürk 2010; Killmann et al. 2003; DPT 2001). ODOÜ'lerin Dünya genelinde yaklaşı 100 milyar \$’ık bir gelir katkısı sağladığı bildirilmektedir (Sharma et al. 1998). Türkiye'de Orman Genel Müdürlüğünün (OGM) bilançolarında yer alan ODOÜ’lerin yaklaşık \%49'u ihraç edilmekte ve yıllık yaklaşık 436 milyon \$'lık bir gelir elde edilmektedir (Kurt ve ark. 2016). 
Türkiye ODOÜ'ler açısından önemli ekonomik potansiyele sahip olmasına karşın, henüz bu ürünlere ilişkin envanterler tam olarak oluşturulamamıştır (Türker ve ark. 2000). Diğer yandan, OGM tarafından yapılan üretimlerin yanı sıra orman köylülerinin kayıt dışı ve kontrolsüz şekilde geleneksel yöntemlerle yaptığı üretimler söz konusudur (Bilir 2017). Tüm doğal kaynak kullanımlarında olduğu gibi ODOü'lerde de kaynakların varlığının ve faydalanmanın sürekliğinin sağlanması esastır. Ancak, orman alanları içinde veya bitişiğinde yaşayan orman köylüleri, bu alanlardaki kaynaklardan doğrudan yararlanırken, uygulanacak yönetim stratejilerinden ilk etkilenecek toplumsal grup konumundadır (Altunel 2012). ODOÜ kaynaklarının daha verimli şekilde değerlendirilebilmesi, üretim faaliyetlerinin kayıt ve kontrol altına alınabilmesi ve sürdürülebilirliğin sağlanabilmesi amacıyla geliştirilecek stratejilerde orman köylülerinin göz ardı edilmemesi gereklidir (Altunel 2012; Walter et al. 2003).

Bu çalışma, ODOÜ için ilk toplayıcı, kullanıcı ve pazarlayıcı konumundaki orman köylülerinin, bu ürünlerden ekonomik açıdan faydalanma durumlarını ve farkındalık düzeylerini belirlemeyi amaç edinmiştir.

\section{MATERYAL ve YÖNTEM}

Çalışma alanı olarak, ODOÜ açısından önemli potansiyele sahip olması yanı sıra söz konusu ürünlerin tarımının yapılabilmesi için gerekli nitelikleri taşıdığı bildirilen (Güldaş ve Çok 2006) Elazığ Orman Bölge Müdürlüğü (OBM) sorumluluk alanı seçilmiştir. Bu kapsamda çalışmanın birincil verilerini Elazığ OBM sorumluluk alanı içinde yer alan orman köylerindeki yerel halka uygulanan anketler oluşturmuştur.

Elazığ OBM bünyesinde Bingöl, Bitlis, Elazığ, Hakkâri, Malatya, Muş, Tunceli ve Van Orman İşletme Müdürlükleri yer almaktadır. Elazığ OBM sorumluluk alanında toplam 1.283.596 Ha orman alanı mevcut olup, \%31'i normal, \%69'u bozuk orman formu şeklindedir (Çizelge 1) (URL-1 2018).

Çizelge 1 Elazığ OBM orman varlığı (URL-1 2018)

\begin{tabular}{llllllllll}
\hline Orman Formu & Bingöl & Bitlis & Elazı̆ & Hakkâri & Malatya & Muş & Tunceli & Van & Toplam \\
\hline Normal (Ha) & 46701 & 71542 & 42762 & 35278 & 48480 & 29651 & 119043 & 4796 & 398253 \\
Bozuk (Ha) & 218233 & 108695 & 127130 & 112934 & 140860 & 48775 & 105218 & 23498 & 885343 \\
Toplam & 264934 & 180237 & 169892 & 148212 & 189340 & 78426 & 224261 & 28294 & 1283596 \\
\hline
\end{tabular}

Genel değerlendirme yapılarak ve literatürdeki çalışmalardan faydalanılarak (Bilir 2017; Korkmaz ve Fakir 2009) hazırlanan veri toplama aracı 23 farklı orman köyünde toplam 144 orman köylüsüne yüz yüze görüşme yöntemi ile uygulanmıştır. Veri toplama aracı olarak belirlenen anket, 14 adet soru ve katılımcıların farkındalık düzeyini belirlemeye yönelik $5^{\prime}$ li likert yapısıyla hazırlanmış 16 önermeden oluşturulmuştur.

TUik 2017 yılı verilerine göre TRB1 (Malatya, Elazığ, Bingöl, Tunceli) ve TRB2 (Van, Mu, Bitlis, Hakkâri) alt nüfus bölgelerinde belde ve köyler nüfusu toplamı 761 496 kişidir (URL-2 2017). Evrenden alınması gereken asgari örneklem sayısı evrendeki eleman sayısı bilinen uygulamalar için Denklem (1) yardımıyla hesaplanmıştır (Baş 2006).
$n=\left[N \cdot t^{2} \cdot p \cdot q\right] /\left[d^{2} \cdot(N-1)+t^{2} \cdot p \cdot q\right]$

$\mathrm{N}=$ Evrendeki eleman sayısı

$\mathrm{n}=$ Alınacak örneklem sayısı

$\mathrm{t}=$ Güven katsayısı (\%95'lik güven için 1,96)

$p=$ Ölçülmek istenilen niteliğin evrende bulunma ihtimali $q=$ Ölçülmek istenilen niteliğin evrende bulunmama ihtimali (1-p)

$\mathrm{d}=$ Örnekleme hatası (\%10)

Buna göre, alınması gereken örneklem sayısı en az 96 olarak hesaplanmış olup, araştırmada ise 144 katılımcıya ulaşılmıştır.

Çalışmada elde edilen verilerin çizelgelenmesi, yüzdelik oranlara dönüştürülmesi ve grafiklerin oluşturulmasında Microsoft Excel paket programı kullanılmıştır. İstatistiksel analizler için SPSS 20.0 paket programından 
yararlanılmıştır. Kullanılacak istatistiki yöntemi tespit edebilmek amacıyla verilere Tek Örneklem KolmogorovSmirnov testi uygulanmış ve tüm önermeler için $p<0.05$ anlamlılık değerine ulaşılmıştır. Dolayısıyla verilerin homojen dağılmadığı görülmüş olup (Baştürk 2011) nonparametrik testlerin kullanılmasına karar verilmiştir. Gruplar arası görüş farklıııklarını tespite yönelik üç veya daha fazla bağımsız örneklemli karşılaştırmalar için Kruskal-Wallis Varyans Analizi kullanılmıştır. Bu analizlerde, test değişken grubunu oluşturan 16 maddelik önerme, benzer niteliği ölçmeyi hedefleyen maddeler halinde gruplandırılarak 4 ana gruba indirgenmiştir.

\section{BULGULAR ve TARTIŞMA}

\section{Verilerin Geçerlilik ve Güvenirliği}

Çalışmada, veri toplama aracının ölçülmek istenen niteliği ölçebilme yeteneği olarak tanımlanan geçerliliği test edebilmek amacıyla, kısmi ve gözlenen korelasyon katsayılarının karşılaştııılması ilkesini esas alan KaiserMeyer-Olkin (KMO) geçerlilik testi kullanılmıştır. Analiz sonuçlarına göre KMO katsayısı 0.648 ve anlamlılık değeri (p) 0.000 olarak hesaplanmış ve yeterli geçerlilik düzeyinin sağlandığı (Kalaycı 2010) görülmüştür.

Yapılan ölçümün tutarlılığı olarak tanımlanan güvenirlik analizi için Cronbach Alfa yöntemi kullanılarak güvenirlik katsayısı 0.801 olarak hesaplanmış ve verilerin yeterli güvenirlik düzeyini sağladığı (Kalaycı 2010) anlaşıımıştır.

\section{Katılımcıların Demografik Özelliklerine ìlişkin Bulgular}

Katılımcıların 48'i kadın (\%33) ve 96'sı (\%67) erkek olarak gerçekleşirken en yüksek katılım 41-60 yaş grubunda oluşmuştur. Katılımcıların $\% 50$ 'sı ilköğretim ve alt öğrenim düzeyi grubunda yer almış olup, en yüksek katılım ise $\% 44$ ile ilköğretim öğrenim düzeyinde gerçekleşmiştir. Katılımcıların \%64'ünün aylık gelirinin 2 500 TL'nin altında olduğu, \%39'unun çiftçilik ve \%29'unun hayvancllıkla gelir elde ettiği tespit edilmiştir. Diğer yandan, katılımcıların \%32'sini emekli-memur-işçi grubu oluşturmuştur (Çizelge 2).

Çizelge 2 Katılımcıların bazı niteliklere göre dağılımı

\begin{tabular}{|c|c|c|c|}
\hline Nitelikler & Değişkenler & Frekans & Oran (\%) \\
\hline \multirow{5}{*}{ Yaş } & $18-25$ & 24 & 17 \\
\hline & $26-40$ & 24 & 17 \\
\hline & $41-60$ & 66 & 46 \\
\hline & $>=61$ & 30 & 21 \\
\hline & Toplam & 144 & 100 \\
\hline \multirow{5}{*}{ Öğrenim Durumu } & Okuryazar değil & 9 & 6 \\
\hline & Illköğretim & 63 & 44 \\
\hline & Lise & 48 & 33 \\
\hline & Üniversite & 24 & 17 \\
\hline & Toplam & 144 & 100 \\
\hline \multirow{5}{*}{ Gelir Durumu } & 0-500TL & 12 & 8 \\
\hline & $501-1500$ & 30 & 21 \\
\hline & $1501-2500$ & 39 & 27 \\
\hline & $\geq 2500$ & 63 & 44 \\
\hline & Toplam & 144 & 100 \\
\hline \multirow{5}{*}{ Meslek } & Çiftçilik & 56 & 39 \\
\hline & Hayvancılık & 42 & 29 \\
\hline & Emekli & 24 & 17 \\
\hline & Memur-İş̧i & 22 & 15 \\
\hline & Toplam & 144 & 100 \\
\hline
\end{tabular}

\section{Odun Dışı Orman Ürünlerine İlişkin Bulgular}

Katılımcıların \%65'i sağlıklı kalmak ve sağlık sorunlarını gidermek amacıyla ODOÜ’leri kullandığını beyan ederken, $\% 28^{\prime} i$ ise bu ürünleri keyif aldığı için kullandığını bildirmiştir (Korkmaz ve Fakir 2009). ODOÜ'lerin nihai tüketici özellikleri üzerinde durdukları çalışmalarında, bu ürünlerin genel itibariyle sağlık amacıyla kullanıldığını bildirmiştir. Orman kaynaklarından faydalanma 
durumuna ilişkin soruya katılımcıların \%35'i yeterince faydalanıyorum, $\% 45$ si faydalanma yetersizdir ve $\% 27^{\prime} \mathrm{i}$ ise hiçbir şekilde fayda sağlamadıkları yönünde cevap vermiştir. Diğer yandan, katılımcıların \%38'inin orman kaynaklı herhangi bir gelirinin bulunmadığı, toplam \%34'ünün 1000 TL'nin üzerinde bir gelire sahip olduğu belirlenmiştir (Şekil 1). Orman köylülerinin orman kaynaklarından sağladıkları gelirleri konu edinen çalışmalarda (Ulusoy ve ark. 2014; Altunel 2012), bu araştırmanın bulgularını destekler nitelikte sonuçlara ulaşıldığı görülmüştür. Dolayısıyla, orman köylülerinin orman kaynaklarından elde ettikleri gelirlerin aile bütçesine önemli katkılar sağladığı, ancak bu gelirin aile geçimi için yeterli düzeye ulaşmadığı (Türker ve Yılmaz 2010; Sağlam ve Öztürk 2008) söylenebilecektir.

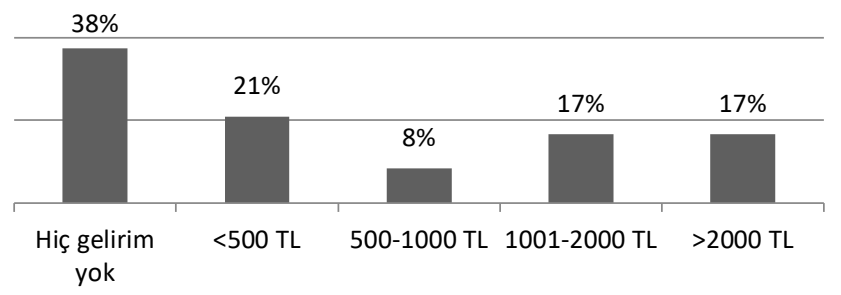

Şekil 1 Katılımcıların orman kaynaklı gelir durumları Katılımcıların \%75'i ODOÜ kullanımına aile büyükleri ve yakın çevrenin tavsiyesi ile başlarken, doktor tavsiyesi ile kullanım ise sadece \%4 düzeyinde gerçekleşmiştir. Diğer yandan televizyon ve radyo reklamlarının (\%13) dergi, kitap ve gazete tanıtımından (\%8) daha etkili olduğu anlaşılmıştır (Şekil 2). Benzer şekilde, literatürde yer alan bazı çalışmalarda (Faydaoğlu ve Sürücüoğlu 2011; Korkmaz ve Fakir 2009), ODOÜ'lerin kullanımında geçmişten günümüze kadar süregelen geleneklerin önemli bir rol oynadığı bildirilmiştir.

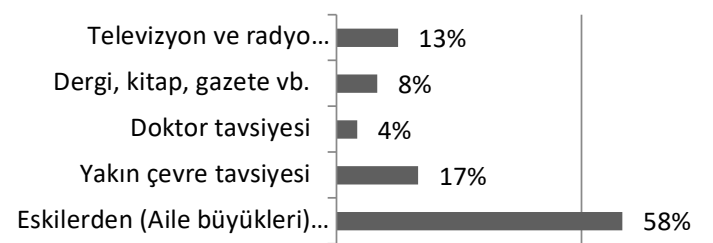

Şekil 2 Katılımcıların ODOÜ kullanımına başlama nedenleri

Katılımcıların \%44'ü ODOÜ'lerin orman köylüsü tarafından üretilmesi gerektiğini düşünürken, $\% 15^{\prime} \mathrm{i}$ Devlet Orman İşletmeleri ve yine \%15'i üretimin ODOü ticaretini yapanlar tarafından üretilmesi gerektiği görüşünü savunmuştur (Çizelge 3). Türkiye'de kırsal kalkınmanın sağlanabilmesinin kırsal göçün azaltılması ve orman köylüsüne yerleşim alanlarında geçim kaynağı oluşturulmasına bağı olduğunu bildiren çalışmalar (Daşdemir ve Söğüt 2017; Alkan 2014), ODOÜ üretiminin orman köylüsü tarafından yapılması gerektiği yargısını destekler niteliktedir.

Çizelge 3 Katılımcılara göre ODOÜ üretimini gerçekleştirmesi gereken birimler

\begin{tabular}{lll}
\hline Tavsiye Edilen Birim & Frekans & Oran (\%) \\
\hline Devlet Orman İşletmeleri & 21 & 15 \\
Orman Köylüsü & 63 & 44 \\
Tüccarlar & 21 & 15 \\
Diğer & 39 & 27 \\
Toplam & $\mathbf{1 4 4}$ & $\mathbf{1 0 0}$ \\
\hline
\end{tabular}

Çalışmanın yapıldığı orman köylerinde meşe mazısı, mantar, alıç, ışkın, kekik, kuşburnu, dağ sarımsağı, badem, kenger ve defne en çok kullanılan ODOÜ arasında yer alırken, bu ürünlerden sadece meşe mazısı, mantar, ışıın, kekik ve kozalak orman köylüsü için gelir getirici ODOÜ olarak değerlendirilebildiği belirlenmiştir (çizelge 4). Katılımcılar tarafından en çok kullanılan ODOÜ \%51 ile mantar olurken bu ürün aynı zamanda \%17'lik oranla en fazla ticareti yapılan ürün olduğu görülmüştür. Göksu ve Adanacıoğlu (2018), bilgi ve denetim yetersizliği, düzensiz faydalanma ve ilk toplayıcı/üretici durumundaki orman köylüleri ile orman ürünleri endüstrisi işletmeleri ve OGM arasındaki iletişim eksikliklerinin ODOÜ'lerin ticari anlamda değerlendirilememesi sonucuna yol açtığını bildirmiştir.

Çizelge 4 Çalışma alanında kullanılan ve ticareti yapılan ODOÜ'ler

\begin{tabular}{ccccccccc}
\hline \multirow{2}{*}{ ODoü } & \multicolumn{3}{c}{ Kullanılan } & & \multicolumn{3}{c}{ Ticareti Yapılan } \\
\cline { 2 - 4 } \cline { 6 - 8 } & Durum & Katılımc & Oran & & Durum & Katılımc & Oran \\
\hline Meşe & + & 15 & 10 & & + & 15 & 10 \\
Mantar & + & 73 & 51 & & + & 24 & 17 \\
Alıç & + & 28 & 19 & & - & & \\
Işkın & + & 37 & 26 & & + & 18 & 13 \\
Kekik & + & 49 & 34 & & + & 12 & 8 \\
Kuşbur & + & 4 & 3 & & - & & \\
Dağ & + & 12 & 8 & & - & & \\
Badem & + & 12 & 8 & & - & & \\
Sahlep & + & 7 & 5 & & - & & \\
Kenger & + & 3 & 2 & & - & & \\
Defne & + & 3 & 2 & & - & & \\
Kozalak & - & & & & + & 10 & 7 \\
\hline
\end{tabular}




\section{Gruplar Arası Görüş Farklılıklarına ilişskin Bulgular}

Katılımcılar arasında, meslek gruplarına göre ODOÜ'lerin doğrudan kullanımı ve elde edilen gelir faydaları ile ODOÜ'lere ilişkin farkındalığın yetersiz olduğu ve desteklenmesi gerektiğini bildiren yargılara ilişkin istatistiksel düzeyde anlamlı görüş farklılıkları $(p<0.05)$ olduğu görülmüştür (Çizelge 5). Buna göre, çiftçilikle uğraşan katılımcılar doğrudan kullanım ve sağladıkları ekonomik gelir bakımından ODOÜ'lerin faydasını önemli bulurken, emekli katılımcılar ise sağlanan faydaların önemini en alt düzeyde değerlendirmiştir. Benzer şekilde, ODOÜ farkındalı̆ıının yetersiz olduğu ve eğitimlerle geliştirilmesi çiftçiler ve hayvancılıkla uğraşan katııımcılar için en üst düzeyde gereklilik iken, emekli-memur grubundaki katılımcılar için hususun gereklilik düzeyi düşük olarak değerlendirilmiştir.

Çizelge 5 Meslek değişkenine göre yargılar ölçeğinde Kruskal-Wallis test sonuçları

\begin{tabular}{|c|c|c|c|c|c|}
\hline Yargılar & Meslek & $\mathbf{N}$ & Sıra Ortalaması & Ki-Kare & $\mathbf{p}$ \\
\hline \multirow{6}{*}{$\begin{array}{l}\text { ODOÜ'lerin Doğrudan Kullanımı ve } \\
\text { Ekonomik Yönden Faydaları }\end{array}$} & Çiftçilik & 56 & 86.51 & & \\
\hline & Hayvancılık & 42 & 61.79 & & \\
\hline & Emekli & 24 & 54.50 & 14.044 & $0.003^{*}$ \\
\hline & Memur & 22 & 76.93 & & \\
\hline & Toplam & 144 & & & \\
\hline & Çiftçilik & 56 & 80.96 & & \\
\hline \multirow{6}{*}{$\begin{array}{l}\text { OGM'nin Çalışmaları ve Kontrolünün } \\
\text { Gerekliliği }\end{array}$} & Hayvancilık & 42 & 67.18 & & \\
\hline & Emekli & 24 & 71.00 & 4.368 & 0.224 \\
\hline & Memur & 22 & 62.75 & & \\
\hline & Toplam & 144 & & & \\
\hline & Çiftçilik & 56 & 77.80 & & \\
\hline & Hayvancılık & 42 & 74.21 & & \\
\hline \multirow[t]{4}{*}{ ODOÜ'ler Hakkında Bilgi Sahibi Olma } & Emekli & 24 & 60.69 & 3.163 & 0.367 \\
\hline & Memur & 22 & 68.61 & & \\
\hline & Toplam & 144 & & & \\
\hline & Çiftçilik & 56 & 83.38 & & \\
\hline \multirow{4}{*}{$\begin{array}{l}\text { Farkındalık ve Eğitimlerin Artırılması } \\
\text { Gerekliliği }\end{array}$} & Hayvancılık & 42 & 71.32 & & \\
\hline & Emekli & 24 & 62.56 & 8.123 & $0.044 *$ \\
\hline & Memur & 22 & 57.91 & & \\
\hline & Toplam & 144 & & & \\
\hline
\end{tabular}

${ }^{*} p<0.05$

Katılımcıların ODOÜ kullanımına başlanmasında etkili olan faktörlere göre gruplandırılmış yargıların 3 adedinde katılımcılar arasında anlamlı görüş farklılıkları bulunduğu $(p<0.05)$ tespit edilmiştir (Çizelge 6$)$. Dergi, kitap ve gazete kaynaklı bilgilerden dolayı ODOÜ kullanmaya başlayan katılımcılar, bu ürünlerin hem kullanım hem gelir sağlama açısından önemli faydaları olduğunu, bu ürünler üzerinde OGM kontrol ve denetiminin güçlendirilmesi gerektiğini ve konu hakkında yeterli bilgi sahibi olduklarını düşünürken, çevre tavsiyesi ve aileden gelen eski deneyimlerle ürünleri kullanan katılımcıların söz konusu hususlara ilişkin farkındalık düzeyinin düşük olduğu görülmüştür. Çalışmalarında benzer sonuçlara ulaşan Yaldız ve arkadaşları (2010), ODOü'lere ilişkin farkındalık düzeyinin düşük olduğunu ve geliştirilmesi gerektiğini bildirmiştir.

Orman kaynaklarından faydalanma durumuna göre ODOÜ'lerin OGM kontrolünde üretilmesi gerekliliği ve bu ürünler hakkında yeterli bilgiye sahip olduğu yargılarına ilişkin katılımcılar arsında anlamlı görüş farklııkları bulunduğu $(p<0.05)$ görülmüştür (Çizelge 7$)$. Orman kaynaklarından yeterince faydalandığını düşünen katılımcı grubunun, ODOÜ'ler hakkında yeterli bilgiye sahip olduklarını, OGM'nin ODOü'lere ilişkin çalışmalarının geliştirilmesi ve bu ürünler üzerindeki kontrolün OGM tarafından sağlanması gerektiğini düşündükleri tespit edilmiştir. Diğer yandan, Çizelge 7'den söz konusu hususlar üzerindeki olumlu düşüncelerin ormandan sağlanan fayda ile doğru orantılı bir ilişki içinde olduğu, faydalanma düzeyinin azalmasıyla 
farkındalık düzeyinin de azaldığı anlaşılmıştır. Dolayısıyla, Birben ve arkadaşlarının (2018) genel olarak toplumun orman kaynakları hakkındaki farkındalık düzeyinin düşük olduğunu bildirdiği çalışma sonuçları ile aynı doğrultuda sonuçların elde edildiği söylenebilir.

\begin{tabular}{|c|c|c|c|c|c|}
\hline Yargılar & Etkenler & $\mathbf{N}$ & Sıra Ortalaması & Ki-Kare & $\mathbf{p}$ \\
\hline \multirow{7}{*}{$\begin{array}{l}\text { ODOÜ'lerin Doğrudan Kullanımı } \\
\text { ve Ekonomik Yönden Faydaları }\end{array}$} & Eskilerden gelen deneyimler & 84 & 67.20 & & \\
\hline & Çevre tavsiyesi & 24 & 47.94 & & \\
\hline & Doktor tavsiyesi & 6 & 90.50 & 28.499 & $0.000^{*}$ \\
\hline & Dergi, kitap, gazete vb. & 12 & 111.50 & & \\
\hline & TV ve radyo reklamları & 18 & 98.00 & & \\
\hline & Toplam & 144 & & & \\
\hline & Eskilerden gelen deneyimler & 84 & 66.13 & & \\
\hline \multirow{6}{*}{$\begin{array}{l}\text { OGM'nin Çalışmaları ve } \\
\text { Kontrolünün Gerekliliği }\end{array}$} & Çevre tavsiyesi & 24 & 61.63 & & \\
\hline & Doktor tavsiyesi & 6 & 87.50 & 15.235 & $0.004^{*}$ \\
\hline & Dergi, kitap, gazete vb. & 12 & 104.38 & & \\
\hline & TV ve radyo reklamları & 18 & 90.50 & & \\
\hline & Toplam & 144 & & & \\
\hline & Eskilerden gelen deneyimler & 84 & 65.48 & & \\
\hline \multirow{6}{*}{$\begin{array}{l}\text { ODOÜ’ler Hakkında Bilgi Sahibi } \\
\text { Olma }\end{array}$} & Çevre tavsiyesi & 24 & 67.06 & & \\
\hline & Doktor tavsiyesi & 6 & 65.00 & 14.542 & $0.006^{*}$ \\
\hline & Dergi, kitap, gazete vb. & 12 & 99.50 & & \\
\hline & TV ve radyo reklamları & 18 & 97.00 & & \\
\hline & Toplam & 144 & & & \\
\hline & Eskilerden gelen deneyimler & 84 & 69.18 & & \\
\hline \multirow{5}{*}{$\begin{array}{l}\text { Farkındalık ve Eğitimlerin } \\
\text { Artırılması Gerekliliği }\end{array}$} & Çevre tavsiyesi & 24 & 71.94 & & \\
\hline & Doktor tavsiyesi & 6 & 83.75 & 5.832 & 0.212 \\
\hline & Dergi, kitap, gazete vb. & 12 & 98.00 & & \\
\hline & TV ve radyo reklamları & 18 & 68.00 & & \\
\hline & Toplam & 144 & & & \\
\hline
\end{tabular}

$* p<0.05$

Çizelge 7 Orman kaynaklarından faydalanma değişkenine göre yargılar ölçeğinde Kruskal-Wallis test sonuçları

\begin{tabular}{|c|c|c|c|c|c|}
\hline Yargılar & Etkenler & $\mathbf{N}$ & Sıra Ortalaması & Ki-Kare & $\mathbf{p}$ \\
\hline \multirow{5}{*}{$\begin{array}{l}\text { ODOÜ'lerin Doğrudan Kullanımı } \\
\text { ve Ekonomik Yönden Faydaları }\end{array}$} & Yeterince faydalanıyor & 51 & 76.21 & & \\
\hline & Faydalanmıyor & 72 & 70.69 & 0.643 & 0.725 \\
\hline & Kısmen faydalanıyor & 21 & 69.71 & & \\
\hline & Toplam & 144 & & & \\
\hline & Yeterince faydalanıyor & 51 & 83.09 & & \\
\hline \multirow{3}{*}{$\begin{array}{l}\text { OGM'nin Çalışmaları ve } \\
\text { Kontrolünün Gerekliliği }\end{array}$} & Faydalanmıyor & 72 & 63.63 & 7.048 & $0.029 *$ \\
\hline & Kısmen faydalanıyor & 21 & 77.21 & & \\
\hline & Toplam & 144 & & & \\
\hline \multirow{4}{*}{$\begin{array}{l}\text { ODOÜ’ler Hakkında Bilgi Sahibi } \\
\text { Olma }\end{array}$} & Yeterince faydalanıyor & 51 & 87.76 & & \\
\hline & Faydalanmıyor & 72 & 59.00 & 15.748 & $0.000^{*}$ \\
\hline & Kısmen faydalanıyor & 21 & 81.71 & & \\
\hline & Toplam & 144 & & & \\
\hline \multirow{4}{*}{$\begin{array}{l}\text { Farkındalık ve Eğitimlerin } \\
\text { Artırılması Gerekliliği }\end{array}$} & Yeterince faydalanıyor & 51 & 81.85 & & \\
\hline & Faydalanmıyor & 72 & 69.56 & 4.991 & 0.082 \\
\hline & Kısmen faydalanıyor & 21 & 59.86 & & \\
\hline & Toplam & 144 & & & \\
\hline
\end{tabular}

${ }^{*} p<0.05$ 


\section{SONUÇ}

Bu çalışmada, Elazığ Orman Bölge Müdürlüğü sorumluluk alanındaki orman köylüsünün ODOü'lere ilişkin farkındalık düzeyi değerlendirilmiştir. Bu kapsamda orman köylülerine anket uygulaması yapılmıştır. Yapılan değerlendirmelere göre, orman köylülerinin orman kaynaklı gelirlerinin beklenen yaşam standardını sağlayabilecek düzeyin altında kaldığı ve bu yerleşim yerlerinde orta ve üst yaş grubundaki nüfusun çoğunluğunu oluşturduğu görülmüştür.

Orman köylerindeki ODOÜ kullanımının büyük ölçüde geleneksel alışkanlık ve deneyimlere bağlı olarak gerçekleştiği ve bilinçli bir faydalanmanın söz konusu olmadığı anlaşılmıştır. Diğer yandan, orman köylüleri tarafından doğrudan kullanılan çok sayıdaki ODOÜ bulunmasına karşın, ticareti yapılan ürün sayısının çok daha az olduğu görülmüştür.

Yapılan çalışma, çiftçilikle uğraşan orman köylülerinin ODOÜ'ler hakkında daha fazla bilgi sahibi olduklarını ve faydalanma düzeyi arttıkça bu ürünlere ilişkin bilgi düzeyinin arttığını ortaya koymuştur. Ancak genel itibariyle, orman köylülerinin ODOÜ’lere ilişkin farkındalık düzeyinin düşük olduğu ve geliştirilmesi gerektiği açıktır. ODOÜ kaynaklarının ve faydalanmanın sürdürülebilirliği için üretimin konu hakkında eğitimli bireyler tarafından yapılması ve OGM birimlerinin kontrol ve denetim mekanizmalarının güçlendirilmesi gereklidir.

En yüksek farkındalık düzeyinin dergi, kitap, gazete vb. kaynaklı olduğu dikkate alınarak, eğitim kurumlarında ormanların ODOÜ’ler dâhil işlevsel nitelikleri hususunda daha fazla bilinçlendirme yapılması bir gerekliliktir. Diğer yandan, dergi, gazete vb. medya iletişim araçlarında konuya daha fazla yer verecek çalışmalar yapılması sağlanmalıdır.

OGM'nin ODOÜ'lere ilişkin envanter çalışmalarının neticelendirilmesi sağlanmalı, üretim ve pazarlama faaliyetleri OGM ve orman köylüsü iş birliğinde yürütülerek ODOü'lerin kırsal kalkınmadaki etkinliği geliştirilmelidir.

\section{TEŞEKKÜR}

Bu çalışma 4. Uluslararası Odun Dışı Orman Ürünleri Sempozyumunda (4-6 Ekim 2018 Bursa) sözlü bildiri olarak sunulmuştur.

\section{KAYNAKLAR}

Alkan S (2014) Kırsal nüfus değişiminin ormanlar ve ormanclık üzerine etkileri (Trabzon ili örneği). Kastamonu Üniversitesi Orman Fakültesi Dergisi, 14(1), 69-78

Altunel TA (2012) Odun dışı orman ürünlerinin toplayıcı/üretici açısından sosyoekonomik önemi. Journal of the Faculty of Forestry Istanbul University, 62(1):85-99

Baş T (2006) Anket Nasıl Hazırlanır Uygulanır Değerlendirilir. Seçkin Yayıncılık 4. Baskı, Ankara

Baştürk R (2011) Bütün Yönleriyle SPSS Örnekli Nonparametrik İstatistik Yöntemler. Anı Yayıncılık, 2. Baskı, Ankara

Bilir A (2017) Odun dışı orman ürünlerine yönelik toplumsal algının belirlenmesi: Kahramanmaraş ili örneği. KSÜ Fen Bilimleri Enstitüsü Orman Müh. ABD, Yüksek Lisans Tezi, Kahramanmaraş, $84 \mathrm{~s}$

Birben Ü, Ünal HE, Karaca A (2018) Orman kaynaklarına ilişkin toplumsal algının incelenmesi (Çankırı kent merkezi örneği). Türkiye Ormancılık Dergisi, 19(1): 76-82

Daşdemir í, Söğüt T (2017) Bartın'da odun dışı orman ürünleri ve değerlendirme olanakları. İnsan ve Doğa Etkileşiminde Orman ve Ormancılık, IV. Ormancilık Kongresi, Antalya, Cilt:2, 13-27

DPT (2001) Ormancılık özel intisas komisyonu raporu. Devlet Planlama Teşkilatı, VIII. Beş Yıllık Kalkınma Planı (BYKP). DPT Yayın No: 2531, Öik Yayın No: 547

Faydaoğlu E, Sürücüoğlu MS (2011) Geçmişten günümüze tıbbi ve aromatik bitkilerin kullanılması ve ekonomik önemi. Kastamonu Üniversitesi Orman Fakültesi Dergisi, 11(1), 52-67

Göksu E, Adanacıoğlu H (2018) Türkiye' de odun dışı orman ürünlerinde doğrudan pazarlama. Türkiye Ormancılık Dergisi, 19(2): 210-218

Güldaş N, Çok A (2006) Odun dışı orman ürünlerinin Doğu Anadolu için önemi. I. Odun Dışı Orman Ürünleri Sempozyumu, Trabzon, 131138

Janse G, Ottitsch A (2005) Factors influencing the role of non-wood forest products and services. Forest Policy and Economics, 7:3, pp 309-319

Kalaycı Ş (2010) SPSS Uygulamalı Çok Değişkenli i̇statistik Teknikleri. Asil Yayın Dağıtım, 5. Baskı, Ankara

Killmann W, Ndeckere F, Vantomme P, Walter S (2003) Developing inventory methodologies for the elaboration of national level statistics on NWFP: Lessons learned from case studies and from a global assessment. Sustainable Production of Wood and NonWood Forest Products, 604 (5): 83-87

Komut O, Öztürk A (2010) Gümüşhane yöresinde odun dışı orman ürünleri işletmeciliği: Mevcut durum, sorunlar ve öneriler. III. Ulusal Karadeniz Ormancılık Kongresi, Cilt: 3, 1167-1175 
Korkmaz M, Fakir H (2009) Odun dışı bitkisel orman ürünlerine ilişkin nihai tüketici özelliklerinin belirlenmesi. SDÜ Orman Fakültesi Dergisi, Seri: A, Sayı: 2, 10-20

Kurt R, Karayılmazlar S, İmren E, Çabuk Y (2016) Türkiye ormancılık sektöründe odun dışı orman ürünleri: ìhracat analizi. Journal of Bartın Faculty of Forestry, 18(2): 158-167

OGM (2016) Odun dışı orman ürünlerinin envanter ve planlaması ile üretim ve satış esasları. Orman Genel Müdürlüğü Tebliğ No: 302, Ankara

Sağlam B, Öztürk A (2008) Orman koruma faaliyetlerinde etkinliğin artırılmasında orman köylüsü-ormancılık teşkilatı ilişkileri: Artvin Orman Bölge Müdürlüğü örneği. Kastamonu Üniversitesi Orman Fakültesi Dergisi, 8(2), 131-143

Sharma E, Sundriyal RC, Rai SC, Krishna AP (1998) Watershed: a functional unit of management for sustainable development. In: Ambasht, R.S. (Ed.), Modern trends in Ecology and Environment. Backhuys Publishers, Leiden, The Netherlands, pp. 171-185

Türker MF, Öztürk A, Tiryaki E (2002) Ülkemiz ormancılık sektöründe odun dışı orman ürünleri kapsamında değerlendirilen odun dışı bitkisel ürünlerin işletmeciliği. II. Ulusal Karadeniz Ormancılık Kongresi, Cilt 1, 270-279

Türker MF, Pak M, Öztürk A (2000) The Review of non-wood forest products management in Turkey as from the five year development plans and forestry main plans. Seminar on Harvesting of Non-Wood Forest Products, Menemen, İzmir, 2-8 October 2000

Türker MF, Yılmaz C (2010) Doğu Karadeniz, Türkiye ve Dünya ormancılığının sorunları ve bu sorunları doğuran köksorunların irdelenmesi. III. Ulusal Karadeniz Ormancılık Kongresi, Artvin, Cilt: I, 80-92

Ulusoy H, Türkoğlu T, Büyüksakallı H, Malkaçoğlu S (2014) Ormanlardan çok yönlü yararlanmanın işletme düzeyinde değerlendirilmesi (Köyceğiz Orman İşletme örneği). II. Ulusal Akdeniz Orman ve Çevre Sempozyumu, Isparta, 624-636

URL-1 https://elazigobm.ogm.gov.tr/ (Erişim: 25.05.018)

URL-2 https://biruni.tuik.gov.tr/bolgeselistatistik (Erişim: 10.09.2017) Walter S, Vantomme P, Killmann W, Ndeckere F (2003) Benefit sharing arrangements in the field of non-wood forest products. Sustainable Production of Wood and Non-Wood Forest Products. Proceedings of the IUFRO Division 5 Researcg Groups 5.11 and 5.12, Rotorua, New Zealand

Yaldız G, Yüksek T, Şekeroğlu N (2010) Rize ili orman ve kıyı köylülerinin kalkındırılmasında tıbbi ve aromatik bitkilerin önemi. III. Ulusal Karadeniz Ormancılık Kongresi, Artvin, Cilt: 3, 1176-1186 